\title{
SHANK3 Gene
}

National Cancer Institute

\section{Source}

National Cancer Institute. SHANK3 Gene. NCI Thesaurus. Code C75396.

This gene may play a role in neuronal function. 